\title{
Characteristics of $\mathrm{Ni} / 3 \mathrm{~d}$ Series Transition Metal $/ \gamma-\mathrm{Al}_{2} \mathrm{O}_{3}$ Catalysts and their Hydrogen Production Abilities from Butane Steam Reforming
}

\author{
Jun Su Lee, Byung-Hyun Choi, ${ }^{\dagger}$ Mi-Jung Ji, ${ }^{\dagger}$ and Misook Kang ${ }^{*}$ \\ Department of Chemistry, College of Science, Yeungnam University, Gyeongsan, Gyeongbuk 712-749, Korea \\ *E-mail: mskang@ynu.ac.kr \\ ${ }^{\dagger}$ Korean Institute of Ceramic Engineering \& Technology (KICET), Geumcheon-gu, Seoul 153-801, Korea \\ Received May 19, 2011, Accepted July 20, 2011
}

\begin{abstract}
The materials composed of the $3 \mathrm{~d}$ series transition metals are introduced into the hydrocarbon steam-reforming reaction in order to enhance the $\mathrm{H}_{2}$ production and abruptly depress the catalytic deactivation resulting from the strong sintering between the $\mathrm{Ni}$ component and the $\gamma-\mathrm{Al}_{2} \mathrm{O}_{3}$ support. The conventional impregnation method is used to synthesize the $\mathrm{Ni} / 3 \mathrm{~d}$ series metal $/ \gamma-\mathrm{Al}_{2} \mathrm{O}_{3}$ materials through the sequentially loading $\mathrm{Ni}$ source and the $3 \mathrm{~d}$ series metal ( $\mathrm{Ti}, \mathrm{V}, \mathrm{Cr}, \mathrm{Mn}, \mathrm{Fe}, \mathrm{Co}, \mathrm{Cu}$, and $\mathrm{Zn}$ ) sources onto the $\gamma-\mathrm{Al}_{2} \mathrm{O}_{3}$ support. The Mnloaded material exhibits a significantly higher reforming reactivity than the conventional $\mathrm{Ni} / \gamma-\mathrm{Al}_{2} \mathrm{O}_{3}$ and the other $\mathrm{Ni} / 3 \mathrm{~d}$ series metal $/ \gamma-\mathrm{Al}_{2} \mathrm{O}_{3}$ materials. Particularly the addition of $\mathrm{Mn}$ selectively improves the $\mathrm{H}_{2}$ product selectivity by eliminating the formation of $\mathrm{CH}_{4}$ and $\mathrm{CO}$. The $\mathrm{H}_{2}$ production is maximized at a value of $95 \%$ over $\mathrm{Ni}(0.3) / \mathrm{Mn}(0.3) / \gamma-\mathrm{Al}_{2} \mathrm{O}_{4}(1.0)$ with a butane conversion of $100 \%$ above $750{ }^{\circ} \mathrm{C}$ for up to $55 \mathrm{~h}$.
\end{abstract}

Key Words : Hydrogen production, Butane steam reforming reaction, Nickel/3d series metal/gamma-alumina, Manganese-loaded material

\section{Introduction}

The catalytic steam reforming of light hydrocarbons such as methane, methanol, ethanol, and dimethyl ether is of significant industrial importance for the production of hydrogen, and has attracted increasing interest in the context of the hydrogen economy. LPG, which is mainly composed of propane and butane gases, offers several advantages: it is easily handled and transported, and the existing infrastructure of the city gas is available for its use. Like propane, $n$-butane is a major constituent of LPG, and its conversion, in the presence of steam, affects the hydrogen yield according to the following equations ${ }^{1-3}$ :

$$
\begin{aligned}
& n-\mathrm{C}_{4} \mathrm{H}_{10}+4 \mathrm{H}_{2} \mathrm{O}=4 \mathrm{CO}+9 \mathrm{H}_{2}, \quad \Delta H^{\mathrm{o}} 298=649.9 \mathrm{~kJ} / \mathrm{mol} \\
& n-\mathrm{C}_{4} \mathrm{H}_{10}+8 \mathrm{H}_{2} \mathrm{O}=4 \mathrm{CO}_{2}+13 \mathrm{H}_{2}, \Delta H^{\mathrm{o}} 298=485.3 \mathrm{~kJ} / \mathrm{mol} \\
& \mathrm{CO}+\mathrm{H}_{2} \mathrm{O}=\mathrm{CO}_{2}+\mathrm{H}_{2}, \quad \Delta H^{\mathrm{o}} 298=41.2 \mathrm{~kJ} / \mathrm{mol}
\end{aligned}
$$

Few studies have been carried out on the steam reforming of $n$-butane. ${ }^{1-3}$ The commercial steam-reforming processes have used Ni-based catalysts because of their acceptably high activity and significantly lower cost in comparison to the alternative precious metal-based catalysts. However, these nickel-based catalysts are susceptible to deactivation through the deposition of carbon, ${ }^{4-6}$ under the steam-reforming conditions, where the metal surfaces are covered with various $\mathrm{CH} x$ intermediates. Without a fast steam gasification step to convert these intermediates to $\mathrm{CO}$ and $\mathrm{H}_{2}$, these adsorbed $\mathrm{CH} x$ species that are present on the $\mathrm{Ni}$ surface can undergo further dehydrogenation, polymerization, and rearrangement into highly stable carbon species that not only have a low reactivity toward the gasification reaction but can also dissolve into or encapsulate the Ni particles. In some cases, the dissolution of these carbon species leads to the growth of carbon whiskers, which eventually destroy the catalyst and plug the reactor. The abrupt catalytic deactivation that occurs at high temperatures above $650{ }^{\circ} \mathrm{C}$ is an especially serious problem for the $\mathrm{NiAlO}_{4}$ catalysts because of the formation of the $\mathrm{NiAlO}_{3}$ spinel structure that results from the strong sintering between $\mathrm{Ni}$ and $\mathrm{Al}$. This deactivation caused the reactor to shutdown and the flow of the feed gases to reverse. ${ }^{7,8}$

To overcome these problems, some researchers have reported $^{9,10}$ that alkali (ex. $\mathrm{MgO}$ )- or noble metal (ex. Pt, Pd)-incorporated, Ni-based catalysts exhibited a stable activity for $\mathrm{H}_{2}$ production, but some problems still exist in terms of the performance, lifetime, and cost of the catalyst. In our previous study, ${ }^{11} \mathrm{Ag}$ component was impregnated into $\mathrm{Ni}-\mathrm{MgAl}_{2} \mathrm{O}_{4}$ in order to reduce the extent of the catalytic deactivation that was caused by the strong sintering between $\mathrm{Ni}$ and $\mathrm{Al}$ during the $n$-butane steam reforming. As a result, the $\mathrm{H}_{2}$ production was maximized at $68 \%$ over $\mathrm{Ni}(9) / \mathrm{Ag}(1) /$ $\mathrm{MgAl}_{2} \mathrm{O}_{4}$ at $700{ }^{\circ} \mathrm{C}$ for up to $53 \mathrm{~h}$ without any catalytic deactivation. However, the complexity in the manufacturing process of the catalyst and the differences in catalytic performance with respect to the loading order were still problems. Therefore, an excellent catalyst, which can be simply prepared and produces a high hydrogen gas yield, must be developed.

In this study, various $\mathrm{Ni} / 3 \mathrm{~d}$ series transition metal $/ \gamma-\mathrm{Al}_{2} \mathrm{O}_{3}$ materials were examined in order to reduce the extent of the catalytic deactivation that was caused by the strong sintering between $\mathrm{Ni}$ and $\mathrm{Al}$ during the $n$-butane steam reforming. The effects of the $3 \mathrm{~d}$ series transition metals on the catalytic 
performance were considered, and the physicochemical properties of the materials were determined using $\mathrm{XRD}, \mathrm{H}_{2}-$ TPR, and XPS analyses. The butane steam reforming reactions were conducted in the temperature range from 400-850 ${ }^{\circ} \mathrm{C}$ at intervals of $50{ }^{\circ} \mathrm{C}$. The effects of the temperature, the steam/butane ratio, and the residence time on the activity and the selectivity of the catalyst were investigated, and the optimum conditions were discussed.

\section{Experimental}

Preparation of $\mathrm{Ni} / 3 d$ Series Transition Metal $/ \gamma-\mathrm{Al}_{2} \mathrm{O}_{3}$ Materials. First, eight materials were prepared by loading the raw materials, including $\mathrm{Ti}, \mathrm{V}, \mathrm{Cr}, \mathrm{Mn}, \mathrm{Fe}, \mathrm{Co}, \mathrm{Cu}$, and $\mathrm{Zn}$, onto $\mathrm{Al}_{2} \mathrm{O}_{3}$ using the incipient wetness impregnation method, and these were compared to $\mathrm{Ni} / \gamma-\mathrm{Al}_{2} \mathrm{O}_{3}$. In this synthesis process, $1.0 \mathrm{~g}$ of $\gamma-\mathrm{Al}_{2} \mathrm{O}_{3}$ (Sasol, 250-425 $\mu \mathrm{m}, 146$ $\left.\mathrm{m}^{2} / \mathrm{g}\right)$ was impregnated with the $3 \mathrm{~d}$-metal nitrate $\left(\mathrm{M}\left(\mathrm{NO}_{3}\right)_{2}\right.$ $6 \mathrm{H}_{2} \mathrm{O}, 30$ wt $\%$ per $\gamma-\mathrm{Al}_{2} \mathrm{O}_{3}$ weight, Junsei Co., Japan) in 25 $\mathrm{mL}$ of isopropyl alcohol. The slurry was homogeneously stirred and evaporated below $70{ }^{\circ} \mathrm{C}$ for $30 \mathrm{~min}$. The $3 \mathrm{~d}-$ $\mathrm{MAl}_{2} \mathrm{O}_{4}$ materials were calcined at $500{ }^{\circ} \mathrm{C}$ for $1 \mathrm{~h}$ in air and impregnated with $30 \mathrm{wt} \%$ of nickel nitrate $\left(\mathrm{Ni}\left(\mathrm{NO}_{3}\right)_{2} \cdot 6 \mathrm{H}_{2} \mathrm{O}\right.$, Junsei co. Japan) with respect to the $3 \mathrm{~d}-\mathrm{MAl}_{2} \mathrm{O}_{4}$ weight. The final samples were also evaporated at $70{ }^{\circ} \mathrm{C}$ for $30 \mathrm{~min}$ and dried in ambient air. These samples were heated in flowing air at a rate of $10{ }^{\circ} \mathrm{C} / \mathrm{min}$ to $500{ }^{\circ} \mathrm{C}$, and then isothermally held at $500{ }^{\circ} \mathrm{C}$ for at least $1 \mathrm{~h}$. The various $\mathrm{Ni} / \mathrm{M} / \gamma-\mathrm{Al}_{2} \mathrm{O}_{3}$ materials were reduced with $\mathrm{H}_{2}$ at $700{ }^{\circ} \mathrm{C}$ for $2 \mathrm{~h}$ and cooled to room temperature under argon gas before the butanesteam reforming reaction.

Characterizations of Ni/3d Series Transition Metal/ $\gamma-\mathrm{Al}_{2} \mathbf{O}_{3}$ Materials. The prepared $\mathrm{Ni} / 3 \mathrm{~d}-\mathrm{M} / \gamma-\mathrm{Al}_{2} \mathrm{O}_{3}$ materials were identified through powder $\mathrm{X}$-ray diffraction analysis (XRD, model PW 1830 from Philips) with nickel-filtered $\mathrm{Cu} \mathrm{K} \alpha$ radiation $(40 \mathrm{kV}, 100 \mathrm{~mA})$ at 2-theta angles of $5-70^{\circ}$. The scan speed was $10^{\circ} / \mathrm{min}$, and the time constant was $1 \mathrm{~s}$. The Brunauer, Emmett and Teller (BET) surface area was measured using a Micrometrics ASAP 2000 instrument. All of the materials were degassed under vacuum at $120{ }^{\circ} \mathrm{C}$ for $1 \mathrm{~h}$ before the BET surface measurements. Then the samples were thermally treated at $300{ }^{\circ} \mathrm{C}$ for $30 \mathrm{~min}$. The BET surface areas of the materials were measured through nitrogen gas adsorption using a continuous flow method with a mixture of nitrogen and helium as the carrier gas. The X-ray photon spectroscopy (XPS) measurements of Ni2p, 3d-M2p, and A12p were recorded with an ESCA 2000 (VZ MicroTech, Oxford, UK) system that was equipped with a non-monochromatic AlK $\alpha(1486.6 \mathrm{eV}) \mathrm{X}$-ray source. The powders were pelletized at $1.2 \times 10^{4} \mathrm{kPa}$ for $1 \mathrm{~min}$, and then the $1.0-\mathrm{mm}$ pellets were stored overnight in a vacuum $\left(1.0 \times 10^{-7} \mathrm{~Pa}\right)$ in order to remove any water molecules from the surface prior to the measurements. The base pressure of the ESCA system was below $1 \times 10^{-9} \mathrm{~Pa}$. The experiments were conducted with a $200-\mathrm{W}$ source power and an angular acceptance of $\pm 5^{\circ}$. The analyzer axis formed an angle of $90^{\circ}$ with the specimen surface. The Shirley function was used to subtract the background in the XPS data analysis. The Ni2p, M3d, and A12p XPS signals were fitted using the mixed Lorentzian-Gaussian curves. The $\mathrm{H}_{2}$-TPR (temperature-programmed reduction) was conducted using the following method. About $0.3 \mathrm{~g}$ of the catalyst was pre-treated under a He flow $(30 \mathrm{~mL} / \mathrm{min})$ at $700{ }^{\circ} \mathrm{C}$ for $2 \mathrm{~h}$ and then cooled to room temperature. The analysis was carried out at an $\mathrm{H}_{2}(10$ vol $\%) / \mathrm{N}_{2}$ flow rate of $30 \mathrm{~mL} / \mathrm{min}$ while the temperature of the catalyst was raised from room temperature to $700{ }^{\circ} \mathrm{C}$ at a rate of $5{ }^{\circ} \mathrm{C} / \mathrm{min}$. The change in the hydrogen concentration was measured using a gas chromatograph (GC series 580, GOW-MAC) that was equipped with a TCD. The temperature-programmed oxidation (TPO) was performed using a Shimadzu DT-40 thermo-gravimeter in order to study the formation of the carbon on the material surface through the introduction of 5\% oxygen in helium into the system after it was purged with helium. A $20 \mathrm{mg}$ sample was placed in a sample pan and heated from 50 to $850{ }^{\circ} \mathrm{C}$ at a constant heating rate of $10{ }^{\circ} \mathrm{C} / \mathrm{min}$. High-purity air, composed of $21 \%$ oxygen and $79 \%$ nitrogen, was used as the $\mathrm{O}_{2}$ gas source. The gas mixture was diluted to $5 \%$ in helium gas, and then the diluted gases flowed into the TPO system at a flow rate of $40 \mathrm{~mL} / \mathrm{min}$ in order to combust the carbon that had accumulated on the catalyst after the reaction. The profiles were obtained in the same manner that was described for the TPO, and the coke content was calculated from the weight loss in the temperature range from 50 to $850^{\circ} \mathrm{C}$. $\alpha$-Alumina $(20 \mathrm{mg}$ ) was used as the reference. The amounts of CO and $\mathrm{CO}_{2}$ were calibrated by injecting a known amount of the gases from a sample loop into an injection valve in the bypass line.

Apparatus for Butane Steam-reforming Reaction. The butane steam-reforming activity was measured over the nine materials, Ni/non, Ti, V, Cr, Mn, Fe, Co, Cu, and $\mathrm{Zn} / \gamma-$ $\mathrm{Al}_{2} \mathrm{O}_{3}$, in the temperature range of $400-850{ }^{\circ} \mathrm{C}$ for a the reaction time of $1 \mathrm{~h}$ at a steam-to-butane ratio of $1: 4$ with a GHSV (gas hourly space velocity) of $5500 \mathrm{~h}^{-1}$. The butane gas was directly injected into the reactor, but the water was vaporized in a saturator at a temperature of above $100{ }^{\circ} \mathrm{C}$ before it was injected into the reactor. The resulting steam was injected into the catalytic reforming reactor using helium gas as the carrier gas. The $n-\mathrm{C}_{4} \mathrm{H}_{10}: \mathrm{H}_{2} \mathrm{O}$ ratio of $1: 4$ corresponded to the flow rates of the butane gas and steam at values of 10 and $40 \mathrm{~mL} / \mathrm{min}$, respectively. The materials $(0.5$ g) were pelletized to $20-25$ mesh, packed with a small amount of quartz wool in order to prevent it from moving in the 10 -mm-diameter fixed-bed metal reactor, and vertically mounted inside the furnace. Before the testing, the catalysts were reduced in situ for $1 \mathrm{~h}$ at $700{ }^{\circ} \mathrm{C}$ with $\mathrm{H}_{2}$ gas. Butane that was diluted with He was supplied from the cylinders, and the flow rate was adjusted using a flow meter before the gas was mixed in the mixing tank. The amount of water that was supplied for the vaporization was adjusted using a metering valve, and the water was introduced into the steam generator along with the mixture. This water was converted into vapor in the vapor generator and then sent to the thermal reactor in the mixed gaseous state. The inlet butane concent- 
ration was held constant at $5 \mathrm{kPa}$ (high purity $\mathrm{C}_{4} \mathrm{H}_{10}$ ), whereas the inlet steam concentration varied depending on the inlet $\mathrm{H}_{2} \mathrm{O} / n-\mathrm{C}_{4} \mathrm{H}_{10}$ ratio requirements for each experiment (2.0, 4.0, and 8.0).

After the reactions, the exit gas mixture was transferred via the trace-heated lines to the analysis section, which consisted of a carbosphere column that was equipped with a Donam DS6200 (Donam company, Korea) GC and a mass spectrometer (MS). Gas chromatography was used to investigate the steady state condition experiments, whereas MS was used in the transient carbon formation experiments, where the exit gas was sampled using a quartz capillary and differential pumping. After the reaction, the catalysts were cooled to room temperature in argon gas and subjected to further characterization.

\section{Results and Discussion}

Characteristics of the Ni/3d Series Transition Metal/ $\gamma-\mathrm{Al}_{2} \mathrm{O}_{3}$ Materials. The $\mathrm{Ni} / 3 \mathrm{~d}$ series transition metal $/ \gamma-\mathrm{Al}_{2} \mathrm{O}_{3}$ materials that were both pre-treated and untreated with $\mathrm{H}_{2}$ gas at $700{ }^{\circ} \mathrm{C}$ before the reaction were characterized using $\mathrm{XRD}$ in Figure 1. $\gamma-\mathrm{Al}_{2} \mathrm{O}_{3}$, which acted as the core metal in the materials, was observed as trace peaks at 2-theta angles of $47^{\circ}$ and $68^{\circ}$ in all of the samples, ${ }^{12}$ but these peaks dis-

(a) Before $\mathrm{H}_{2}$ reduction

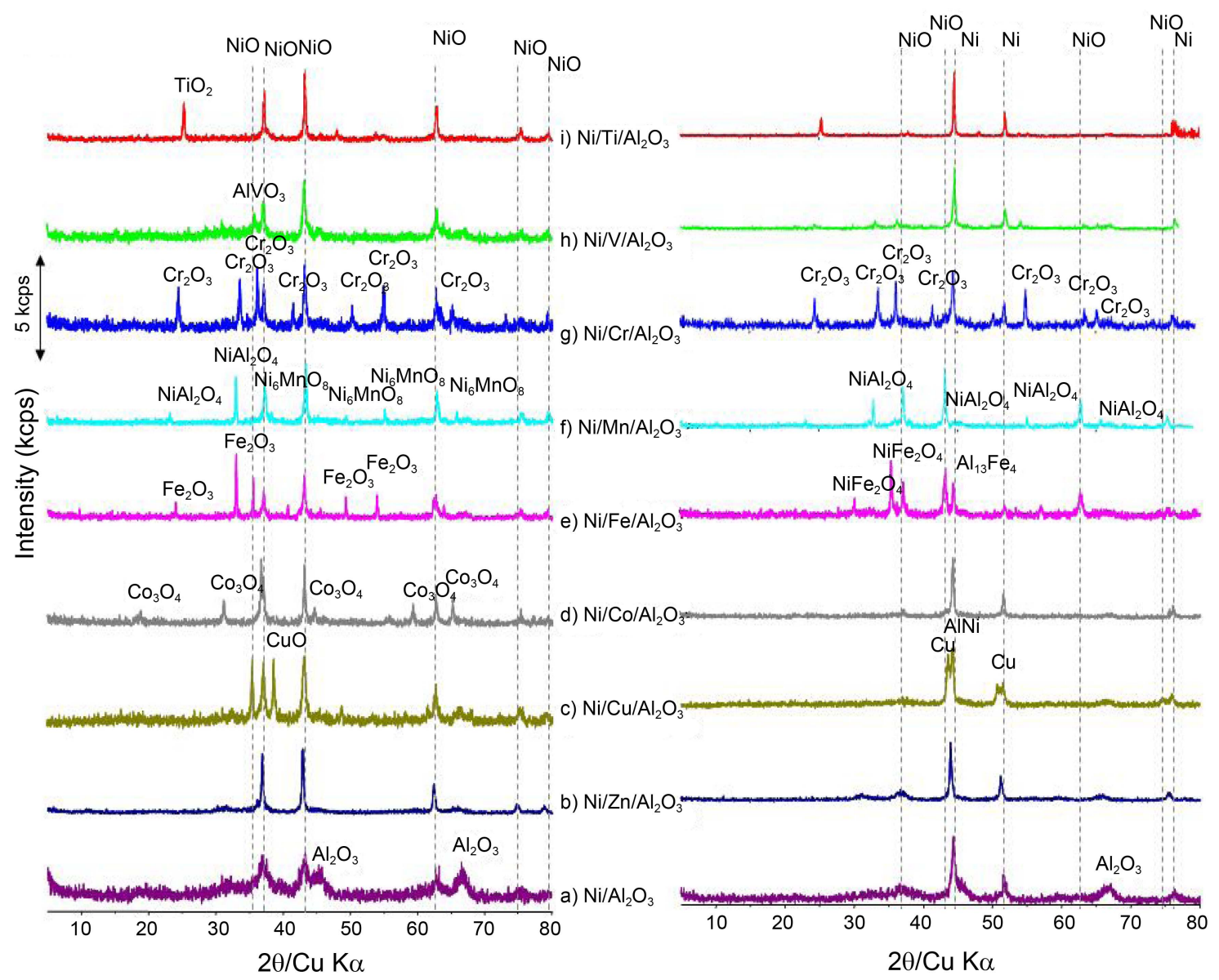

appeared during the hydrogen reduction, except for the $\mathrm{Ni} /$ $\gamma-\mathrm{Al}_{2} \mathrm{O}_{3}$ material, possibly because the $3 \mathrm{~d}$ series transition metals in the other materials completely covered $\gamma-\mathrm{Al}_{2} \mathrm{O}_{3}$, particularly due to the grain growth between the 3-d metals arising from the high temperature treatment. The diffraction lines of the $3 \mathrm{~d}$ series transition metal oxide phases were observed in the XRD patterns of almost all of the materials, and particularly, the $\mathrm{NiMnO}_{\mathrm{x}}$ and $\mathrm{NiAlO}_{\mathrm{x}}$ composites that formed between $\mathrm{Ni}$ and the $\mathrm{Mn}$ or $\mathrm{Al}$ components were only observed in the $\mathrm{Ni} / \mathrm{Mn} / \gamma-\mathrm{Al}_{2} \mathrm{O}_{3}$ material. After the $\mathrm{H}_{2}$ reduction, $\mathrm{MO}_{\mathrm{x}}$ was partially reduced to the $\mathrm{M}^{0}$ oxidation state in most of the materials, and the NiM alloy was also partially observed, particularly in $\mathrm{Ni} / \mathrm{Fe} / \gamma-\mathrm{Al}_{2} \mathrm{O}_{3}$. These results showed that the oxidation states of the main metal components existed between the oxidized and reduced forms.

Table 1 summarizes the physical properties of the nine $\mathrm{Ni} / 3 \mathrm{~d}-\mathrm{M} / \gamma-\mathrm{Al}_{2} \mathrm{O}_{3}$ materials. From the energy dispersive $\mathrm{X}$-ray analysis, the loaded metals were different, with the $\mathrm{Ni}$ and 3-d metal surface atomic concentrations being relatively higher and lower, respectively. The atomic compositions of the exposed $\mathrm{Ni}$ were in the range of $20-59 \%$, and the amount of inserted manganese element in $\mathrm{Ni} / \mathrm{Mn} / \gamma-\mathrm{Al}_{2} \mathrm{O}_{3}$ material was the smallest, indicating that $\mathrm{Ni}$ and $\mathrm{Mn}$ were sequentially covered on the alumina. Generally, the surface area exhibits a strong inverse relation to the particle size.

(b) After $\mathrm{H}_{2}$ reduction

Figure 1. XRD patterns of the nine $\mathrm{Ni} / 3 \mathrm{~d}-\mathrm{M} / \gamma-\mathrm{Al}_{2} \mathrm{O}_{3}$ materials (a) before and (b) after the $\mathrm{H}_{2}$ reduction. 
Table 1. Physical properties, BET surface areas and atomic compositions for the nine $\mathrm{Ni} / 3 \mathrm{~d}-\mathrm{M} / \gamma-\mathrm{Al}_{2} \mathrm{O}_{3}$ materials

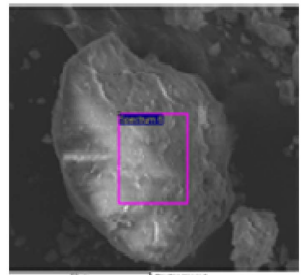

$\mathrm{Ni} / \mathrm{Al}_{2} \mathrm{O}_{3}$

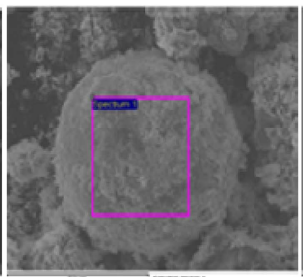

$\mathrm{Ni} / \mathrm{Ti} / \mathrm{Al}_{2} \mathrm{O}_{3}$

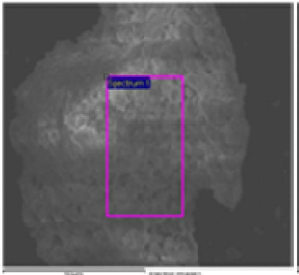

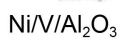

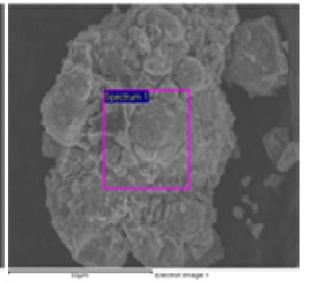

$\mathrm{Ni} / \mathrm{Cr} / \mathrm{Al}_{2} \mathrm{O}_{3}$

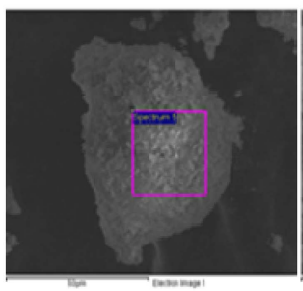

$\mathrm{Ni} / \mathrm{Mn} / \mathrm{Al}_{2} \mathrm{O}_{3}$

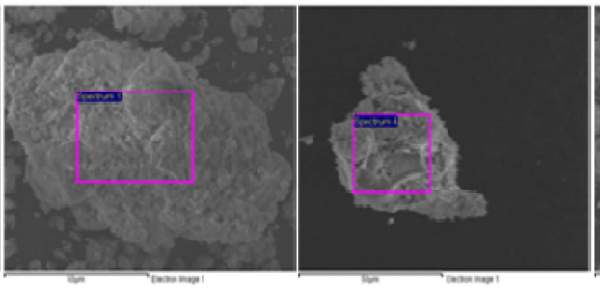

$\mathrm{Ni} / \mathrm{Fe} / \mathrm{Al}_{2} \mathrm{O}_{3}$

$\mathrm{Ni} / \mathrm{Co} / \mathrm{Al}_{2} \mathrm{O}_{3}$

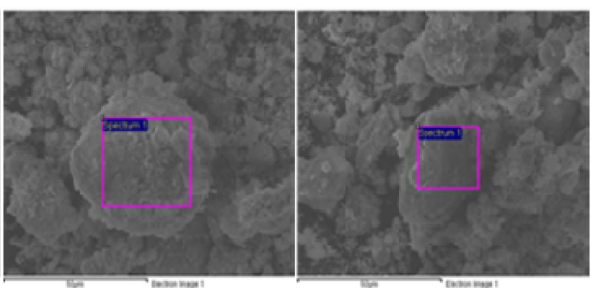

$\mathrm{Ni} / \mathrm{Cu} / \mathrm{Al}_{2} \mathrm{O}_{3}$

$\mathrm{Ni} / \mathrm{Zn} / \mathrm{Al}_{2} \mathrm{O}_{3}$

\begin{tabular}{cccccc}
\hline \multirow{2}{*}{ Catalysts } & BET Surface area $(\mathrm{m} / \mathrm{g})$ & \multicolumn{3}{c}{ Atomic composition $(\mathrm{mol} \%)$} \\
\hline $\mathrm{Ni} / \mathrm{Al}_{2} \mathrm{O}_{3}$ & 108.4085 & $\mathrm{Al}$ & $\mathrm{Ni}$ & $\mathrm{M}$ & $\mathrm{O}$ \\
$\mathrm{Ni} / \mathrm{Ti} / \mathrm{Al}_{2} \mathrm{O}_{3}$ & 58.2504 & 61.54 & 27.60 & - & 40.86 \\
$\mathrm{Ni} / \mathrm{V} / \mathrm{Al}_{2} \mathrm{O}_{3}$ & 59.8055 & 8.22 & 59.80 & 11 & 24.11 \\
$\mathrm{Ni} / \mathrm{Cr} / \mathrm{Al}_{2} \mathrm{O}_{3}$ & 58.4997 & 11.99 & 59.08 & 29.70 & 14.27 \\
$\mathrm{Ni} / \mathrm{Mn} / \mathrm{Al}_{2} \mathrm{O}_{3}$ & 50.4218 & 19.26 & 25.41 & 3.70 & 32.90 \\
$\mathrm{Ni} / \mathrm{Fe} / \mathrm{Al}_{2} \mathrm{O}_{3}$ & 52.4967 & 15.73 & 43.13 & 20.37 & 33.91 \\
$\mathrm{Ni} / \mathrm{Co} / \mathrm{Al}_{2} \mathrm{O}_{3}$ & 45.9168 & 16.76 & 27.95 & 25.96 \\
$\mathrm{Ni} / \mathrm{Cu} / \mathrm{Al}_{2} \mathrm{O}_{3}$ & 51.0888 & 17.62 & 30.51 & 22.36 & 28.99 \\
$\mathrm{Ni} / \mathrm{Zn} / \mathrm{Al}_{2} \mathrm{O}_{3}$ & 57.3261 & 26.17 & 20.61 & 21.11 & 20.51 \\
\hline
\end{tabular}

However, this correlation was not observed in these results. The surface areas and the total pore volumes decreased to a greater extent in the bimetallic-loaded materials $\left(45-59 \mathrm{~m}^{2} /\right.$ $\mathrm{g}, \mathrm{Ni} / 3 \mathrm{~d}$ metal $\left./ \gamma-\mathrm{Al}_{2} \mathrm{O}_{3}\right)$ than in the monometallic-loaded samples $\left(108 \mathrm{~m}^{2} / \mathrm{g}, \mathrm{Ni} / \gamma-\mathrm{Al}_{2} \mathrm{O}_{3}\right)$. This decrease was strengthened by the impregnation of the $3 \mathrm{~d}$ metals melted at high temperature and subsequently interfered with the $\mathrm{Ni}$ and $\mathrm{Al}$ particle spacing in the bulk material.

The $\mathrm{H}_{2}$-TPR profiles of the nine $\mathrm{Ni} / 3 \mathrm{~d}-\mathrm{M} / \gamma-\mathrm{Al}_{2} \mathrm{O}_{3}$ materials are shown in Figure 2. The changes corresponding to the reduction of the 3d-metal oxides and the NiM alloy were observed in the $\mathrm{H}_{2}$-TPR profiles. In general, the $\mathrm{H}_{2}$-TPR results indicated that the peak area corresponded to the hydrogen uptake, and the peak at high temperatures corresponded to the reduction mechanism that was involved in the catalytic reaction. The reduction peak of $\mathrm{NiO}$ gradually shifted to lower temperatures with the additions of $\mathrm{Mn}, \mathrm{Co}$, $\mathrm{V}$, Ti, and $\mathrm{Zn}$, but was shifted to higher temperatures with the $\mathrm{Fe}$ and $\mathrm{Cr}$ additions. Additionally, the NiMn alloy reduction was observed at a low temperature of around 400 ${ }^{\circ} \mathrm{C}$ for $\mathrm{Ni} / \mathrm{Mn} / \gamma-\mathrm{Al}_{2} \mathrm{O}_{3}$. Generally, when the metal components were easily reduced during the hydrocarbon steam reforming reaction, the $\mathrm{H}_{2}$-TPR curve of the metal component was observed at a lower temperature, which induced a higher hydrogen production.

Butane Steam Reforming Reaction over Ni/3d Series

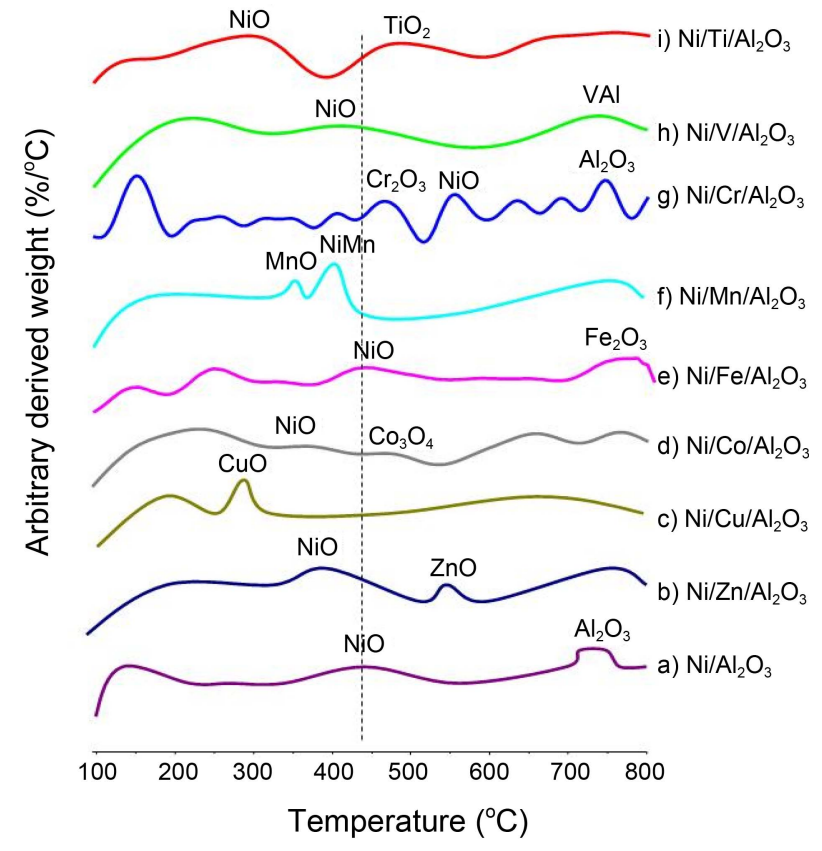

Figure 2. $\mathrm{H}_{2}-\mathrm{TPR}$ curves of the nine $\mathrm{Ni} / 3 \mathrm{~d}-\mathrm{M} / \gamma-\mathrm{Al}_{2} \mathrm{O}_{3}$ materials.

Transition Metal $/ \gamma-\mathbf{A l}_{2} \mathbf{O}_{3}$ Materials. The butane steam reforming was carried out with $0.5 \mathrm{~g}$ of each of the nine materials, with various compositions of the $\mathrm{Ni} / 3 \mathrm{~d}-\mathrm{M} / \gamma-\mathrm{Al}_{2} \mathrm{O}_{3}$, 

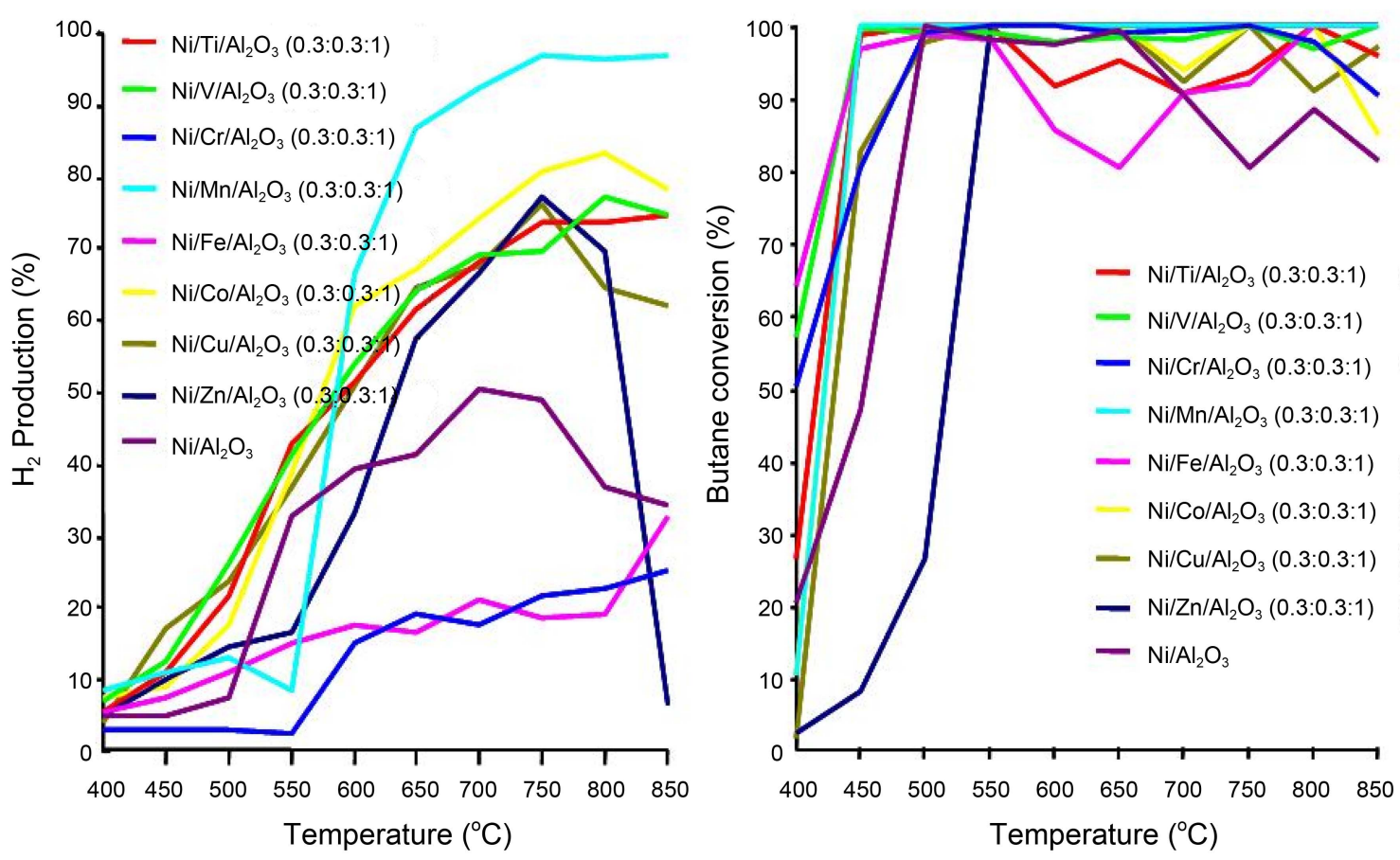

Figure 3. (a) $\mathrm{H}_{2}$ production and (b) butane conversion over the nine $\mathrm{Ni} / 3 \mathrm{~d}-\mathrm{M} / \gamma-\mathrm{Al}_{2} \mathrm{O}_{3}$ materials with respect to the reaction temperature. Reaction conditions: $0.5 \mathrm{~g}$ sample, reaction temperature $=400-850{ }^{\circ} \mathrm{C}, \mathrm{GHSV}=5500 \mathrm{~h}^{-1}$, and $\mathrm{H}_{2} \mathrm{O} / n-\mathrm{C}_{4} \mathrm{H}_{10}=4.0$.

under the reaction conditions of a temperature of 400-850 ${ }^{\circ} \mathrm{C}$, a GHSV of $5500 / \mathrm{h}$, and $\mathrm{H}_{2} \mathrm{O} / n-\mathrm{C}_{4} \mathrm{H}_{10}$ ratio of 4.0 . The $n-\mathrm{C}_{4} \mathrm{H}_{10}$ conversion, $\mathrm{H}_{2}$ production, and selectivity of $\mathrm{CO}$ and $\mathrm{CO}_{2}$ were calculated using the following equations:

$$
\begin{aligned}
& n-\mathrm{C}_{4} \mathrm{H}_{10} \text { conversion }(\%)=\left[\mathrm{C}_{\text {in }} n-\mathrm{C}_{4} \mathrm{H}_{10}-\mathrm{C}_{\text {out }} n-\mathrm{C}_{4} \mathrm{H}_{10}\right] \\
& \quad / \mathrm{C}_{\text {in }} n-\mathrm{C}_{4} \mathrm{H}_{10} \times 100 \\
& \mathrm{CO}_{2} \text { selectivity }(\%)=\mathrm{C}_{\text {out }} \mathrm{CO}_{2} /\left[\mathrm{C}_{\text {out }} \mathrm{CO}_{2}+\mathrm{C}_{\text {out }} \mathrm{CO}\right. \\
& \left.\quad+\mathrm{C}_{\text {out }} n-\mathrm{C}_{4} \mathrm{H}_{10}+\mathrm{C}_{\text {out }} \mathrm{H}_{2}\right] \times 100 \\
& n-\mathrm{CH}_{4} \text { selectivity }(\%)=\mathrm{C}_{\text {out }} n-\mathrm{C}_{4} \mathrm{H}_{10} /\left[\mathrm{C}_{\text {out }} \mathrm{CO}_{2}+\mathrm{C}_{\text {out }} \mathrm{CO}\right. \\
& \left.\quad+\mathrm{C}_{\text {out }} n-\mathrm{C}_{4} \mathrm{H}_{10}+\mathrm{C}_{\text {out }} \mathrm{H}_{2}\right] \times 100 \\
& \text { CO selectivity }(\%)=\mathrm{C}_{\text {out }} \mathrm{CO} /\left[\mathrm{C}_{\text {out }} \mathrm{CO}_{2}+\mathrm{C}_{\text {out }} \mathrm{CO}\right. \\
& \left.\quad+\mathrm{C}_{\text {out }} \mathrm{CH}_{4}+\mathrm{C}_{\text {out }} \mathrm{H}_{2}\right] \times 100 \\
& \mathrm{H}_{2} \text { production }(\%)=\mathrm{mol} \mathrm{H}_{2} /\left[\left(\mathrm{mol} n-\mathrm{C}_{4} \mathrm{H}_{10 \text { in }}-\mathrm{mol}\right.\right. \\
& \left.\left.n-\mathrm{C}_{4} \mathrm{H}_{10 \text { out }}\right)-\left(\mathrm{mol} \mathrm{H}_{2} \mathrm{O}_{\text {in }}-\mathrm{mol} \mathrm{H}_{2} \mathrm{O}_{\text {out }}\right)\right] \times 100 \%
\end{aligned}
$$

The reaction results below $400{ }^{\circ} \mathrm{C}$ were ignored because the butane conversion was less than $50 \%$. Figure 3 compares the time-on-stream activity of the nine materials. In Figure 3(b), the butane conversions were above $90 \%$ at $500{ }^{\circ} \mathrm{C}$ for all of the materials, except $\mathrm{Ni} / \mathrm{Zn} / \gamma-\mathrm{Al}_{2} \mathrm{O}_{3}$ at $550{ }^{\circ} \mathrm{C}$. On the other hand, the $\mathrm{Ni} / \mathrm{Mn} / \gamma-\mathrm{Al}_{2} \mathrm{O}_{3}$ material provided a significantly higher reforming reactivity than the other materials, with a conversion of $100 \%$ at $450{ }^{\circ} \mathrm{C}$. The main products from the steam reforming over the $\mathrm{Ni} / 3 \mathrm{~d}-\mathrm{M} / \gamma-\mathrm{Al}_{2} \mathrm{O}_{3}$ materials were $\mathrm{H}_{2}, \mathrm{CO}, \mathrm{CO}_{2}$, and $\mathrm{CH}_{4}$, with trace amounts of other hydrocarbons. However, the addition of Mn decreased the carbon monoxide and selectively improved the $\mathrm{H}_{2}$ production, because less methane and $\mathrm{CO}$ were emitted than the other materials. The proportion of methane emitted over $\mathrm{Ni} / \mathrm{Mn} / \gamma-\mathrm{Al}_{2} \mathrm{O}_{3}$ was less $\mathrm{Ni} / \gamma-\mathrm{Al}_{2} \mathrm{O}_{3}$. The methanation of carbon dioxide and carbon monoxide on $\mathrm{Ni}$ materials has been observed in many studies. ${ }^{13,14}$ The catalytic performances for the hydrogen production differed according to the added 3-d metals, and the selectivity decreased in the following order: $\mathrm{Ni} / \mathrm{Mn}>\mathrm{Co}>\mathrm{V}>\mathrm{Ti}>\mathrm{Zn}>$ non-metal $>$ $\mathrm{Fe}>\mathrm{Cr} / \gamma-\mathrm{Al}_{2} \mathrm{O}_{3}$ (Figure 3(a)). Although the $\mathrm{H}_{2}$ production over $\mathrm{Ni} / \gamma-\mathrm{Al}_{2} \mathrm{O}_{3}$ reached $48 \%$ at $700{ }^{\circ} \mathrm{C}$, over $\mathrm{Ni} / \mathrm{Mn} / \gamma-\mathrm{Al}_{2} \mathrm{O}_{3}$ it was increased to $95 \%$ at $750{ }^{\circ} \mathrm{C}$, which was quite remarkable compared to the other previously reported results. We also have previously reported ${ }^{11}$ that the $\mathrm{H}_{2}$ production and the butane conversion were $68 \%$ and $100 \%$, respectively, over $\mathrm{Ni}(9) / \mathrm{Ag}(1) / \mathrm{MgAl}_{2} \mathrm{O}_{4}$ at the same conditions as in this study.

Figure 4 shows the product distributions obtained from the butane steam reforming over the $\mathrm{Ni} / \gamma-\mathrm{Al}_{2} \mathrm{O}_{3}$ and $\mathrm{Ni} / \mathrm{Mn} /$ $\gamma-\mathrm{Al}_{2} \mathrm{O}_{3}$ materials, which represented the highest catalytic performance in Figure 3. Unlike Figure 3, the $\mathrm{H}_{2}$ selectivity (\%) was calculated using $\mathrm{C}_{\text {out }} \mathrm{H}_{2} /\left[\mathrm{C}_{\text {out }} \mathrm{CO}_{2}+\mathrm{C}_{\text {out }} \mathrm{CO}+\mathrm{C}_{\text {out }} \mathrm{CH}_{4}\right.$ $\left.+\mathrm{C}_{\text {out }} \mathrm{H}_{2}\right] \times 100 \%$, and the product distributions were equivalent to a butane conversion of $100 \%$. The reactions were conducted at $\mathrm{C}_{4} \mathrm{H}_{10}: \mathrm{H}_{2} \mathrm{O}=1: 4$, a reaction temperature of 750 ${ }^{\circ} \mathrm{C}$, a reaction time of $1 \mathrm{~h}$, and a GHSV of $5500 \mathrm{~h}^{-1}$. Four species, $\mathrm{H}_{2}, \mathrm{CO}, \mathrm{CO}_{2}$, and $\mathrm{CH}_{4}$, were present in the product distribution. In this figure, the hydrogen selectivity was $42 \%$ for $\mathrm{Ni} / \gamma-\mathrm{Al}_{2} \mathrm{O}_{3}$, but the highest hydrogen selectivity of more than $60 \%$ was obtained for $\mathrm{Ni} / \mathrm{Mn} / \gamma-\mathrm{Al}_{2} \mathrm{O}_{3}$, because of the decreased sintering between $\mathrm{Ni}$ and $\mathrm{Al}$ when $\mathrm{Mn}$ was incorporated into the middle of the catalyst, which enhanced the hydrogen selectivity during the butane conversion. Expectedly, the $\mathrm{CO}$ selectivity of the $\mathrm{Ni} / \mathrm{Mn} / \gamma-\mathrm{Al}_{2} \mathrm{O}_{3}$ slightly decreased to below $6 \%$, whereas the $\mathrm{CO}_{2}$ production increased to $8 \%$ compared to the non- $3 \mathrm{~d}$ metal catalyst. The 


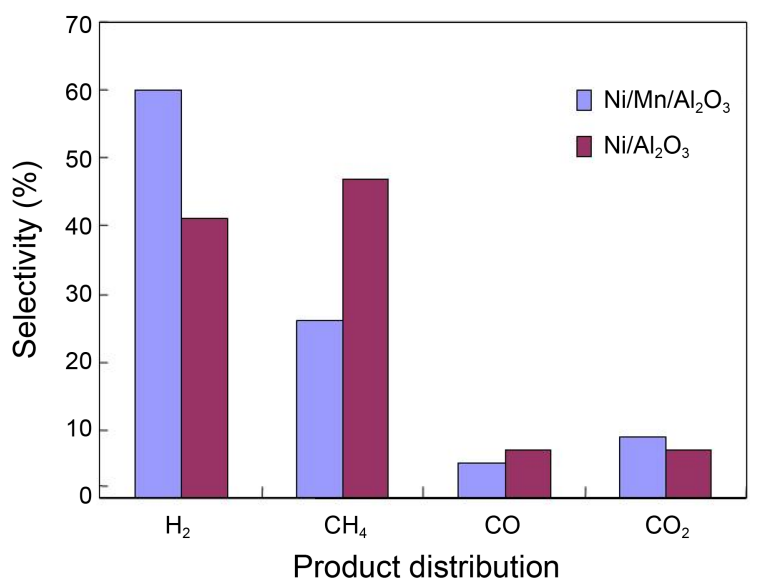

Figure 4. Production distribution during the butane steam reforming over $\mathrm{Ni} / \gamma-\mathrm{Al}_{2} \mathrm{O}_{3}$ and $\mathrm{Ni} / \mathrm{Mn} / \gamma-\mathrm{Al}_{2} \mathrm{O}_{3}$. Reaction conditions: $0.5 \mathrm{~g}$ sample, reaction temperature $=750{ }^{\circ} \mathrm{C}$, reaction time $=$ $1 \mathrm{~h}, \mathrm{GHSV}=5500 \mathrm{~h}^{-1}$, and $\mathrm{H}_{2} \mathrm{O} / n-\mathrm{C}_{4} \mathrm{H}_{10}=4.0$.

presence of $\mathrm{CO}$ degraded the active catalyst due to catalytic poisoning. ${ }^{15}$ Therefore, these results demonstrated that the introduction of the $3 \mathrm{~d}$ transition metals between $\mathrm{Ni}$ and $\mathrm{Al}$ had a synergistic effect on the catalytic performance and decreased the sintering phenomenon, which caused the catalytic deactivation. A particularly strong influence was observed after the Mn addition.

Characteristics of Catalysts after Butane Reforming. Figure 5 compares the XRD patterns of the nine $\mathrm{Ni} / 3 \mathrm{~d}-\mathrm{M} /$ $\gamma-\mathrm{Al}_{2} \mathrm{O}_{3}$ materials after a reaction time of $10 \mathrm{~h}$ at $700{ }^{\circ} \mathrm{C}$. The main peak intensities after the reaction were weaker than the intensities before the reaction shown in Figure 1. The diffraction lines of the $\mathrm{Ni}^{0}$ phase were observed at 2-theta angles of $43^{\circ}$ and $52^{\circ}$ in most of the materials, except for $\mathrm{Ni} / \mathrm{Zn} / \gamma-\mathrm{Al}_{2} \mathrm{O}_{3}$ and $\mathrm{Ni} / \mathrm{Cu} / \gamma-\mathrm{Al}_{2} \mathrm{O}_{3}$. Additionally, the $\mathrm{NiAl}$ alloys at $28^{\circ}$ were not as pronounced in some materials

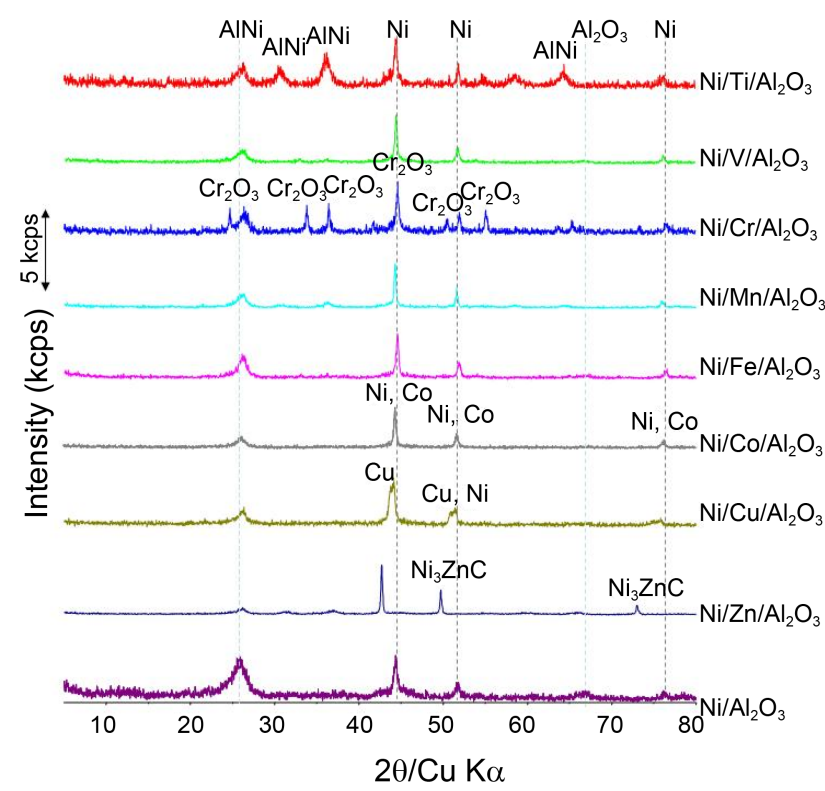

Figure 5. Comparison of the XRD patterns for the nine $\mathrm{Ni} / 3 \mathrm{~d}-\mathrm{M} / \gamma$ $\mathrm{Al}_{2} \mathrm{O}_{3}$ materials after the reaction. compared to $\mathrm{Ni} / \gamma-\mathrm{Al}_{2} \mathrm{O}_{3}$, indicating that the $\mathrm{Ni}$ components acted as active sites in the butane steam reforming reaction, as reported in many studies. ${ }^{16,17}$ Additionally the peaks for the $3 \mathrm{~d}$ metal phases were reduced in the oxidation state after the reaction in all of the materials, except for chromic oxide. Therefore, the $3 \mathrm{~d}$ metal component also served as catalytic active sites similar to $\mathrm{Ni}$, and additionally, the $3 \mathrm{~d}$ metal components helped to retain the stability of the Ni crystallites and avoided their conglomeration in the butane steam reforming reaction. Thus, the $\mathrm{Ni} / 3 \mathrm{~d}-\mathrm{M} / \gamma-\mathrm{Al}_{2} \mathrm{O}_{3}$ materials exhibited a better stability than $\mathrm{Ni} / \gamma-\mathrm{Al}_{2} \mathrm{O}_{3}$.

Figure 6 presents the typical survey and high-resolution spectra that were obtained from the quantitative XPS analysis of the $\mathrm{Ni} / \gamma-\mathrm{Al}_{2} \mathrm{O}_{3}$ and $\mathrm{Ni} / \mathrm{Mn} / \gamma-\mathrm{Al}_{2} \mathrm{O}_{3}$ materials, which exhibited the highest catalytic performance in Figure 3. The survey spectra of the particles contained the A12p, $\mathrm{Ni} 2 \mathrm{p}$, and Mn2p peaks in both before and after the butane steam reforming reactions. Additionally, the C1s peak, which corresponded to the carbon that accumulated over the surfaces of two catalysts, was observed after the butane steam reforming. The A12 $\mathrm{p}_{3 / 2}$ spin-orbital photoelectron, which was assigned to the $\mathrm{Al}$ component in $\gamma-\mathrm{Al}_{2} \mathrm{O}_{3}$, was located at a binding energy of $74.4 \mathrm{eV}$ for the two samples before the reaction. In general, larger binding energies and smaller peak widths indicate more oxidized states. ${ }^{18}$ After the reaction, these peaks shifted to lower binding energies of 73.1 and $72.1 \mathrm{eV}$ for $\mathrm{Ni} / \gamma-\mathrm{Al}_{2} \mathrm{O}_{3}$ and $\mathrm{Ni} / \mathrm{Mn} / \gamma-\mathrm{Al}_{2} \mathrm{O}_{3}$, respectively, and the peaks broadened after the reaction. Generally, the $\mathrm{Ni}_{2} \mathrm{p}_{3 / 2}$ and $\mathrm{Ni} 2 \mathrm{p}_{1 / 2}$ spectra in $\mathrm{NiO}$ are observed at 853.2 and $870.0 \mathrm{eV}$, respectively. ${ }^{18}$ But the peak position can vary depending on the surrounding environment. The peaks were observed at 855.0 and $872.0 \mathrm{eV}$, respectively, after the reaction in this study. However, unfortunately, these peaks were not observed before the reaction for either catalyst because of noise in this study. Therefore, in this case, the changes of oxidation state of $\mathrm{Ni}$ before and after the reaction are difficult to determine.

Additionally, the same phenomenon occurred for Mn2p in $\mathrm{Ni} / \mathrm{Mn} / \gamma-\mathrm{Al}_{2} \mathrm{O}_{3}$. Generally, the $\mathrm{Mn} 2 \mathrm{p}_{3 / 2}$ spin-orbital, which was assigned to $\mathrm{MnO}$, was located at a binding energy of $641.0 \mathrm{eV}$, and this peak shifted to $639 \mathrm{eV}$ after the reaction, corresponding to the $\mathrm{Mn}^{0}$ metal. These results indicated that the $\mathrm{Al}, \mathrm{Ni}$, and $\mathrm{Mn}$ ions were all reduced to lower oxidation states after the butane reforming, which confirmed the involvement of these ions in the oxidations of butane or other hydrocarbons, which occurred during the butane reforming reaction to produce $\mathrm{CO}_{2}$. On the other hand, after the reaction the $\mathrm{C} 1 \mathrm{~s}$ region of the spectra were observed at 284.5 and $282.5 \mathrm{eV}$ for carbon and carbide over $\mathrm{Ni} / \gamma-\mathrm{Al}_{2} \mathrm{O}_{3}$ and $\mathrm{Ni} / \mathrm{Mn} / \gamma-\mathrm{Al}_{2} \mathrm{O}_{3}$, respectively. Thus, the carbon species that accumulated over the catalysts differed according to the metal components of the catalysts because of slight variations in the reaction mechanism.

The TPO measurements were carried out in order to determine the amount of carbon that was deposited on the nine $\mathrm{Ni} / 3 \mathrm{~d}-\mathrm{M} / \gamma-\mathrm{Al}_{2} \mathrm{O}_{3}$ materials, as shown in Figure 7 . The deposited amount and species of carbons were closely 
(a) $\mathrm{Ni} / \mathrm{Mn} / \mathrm{Al}_{2} \mathrm{O}_{3}$

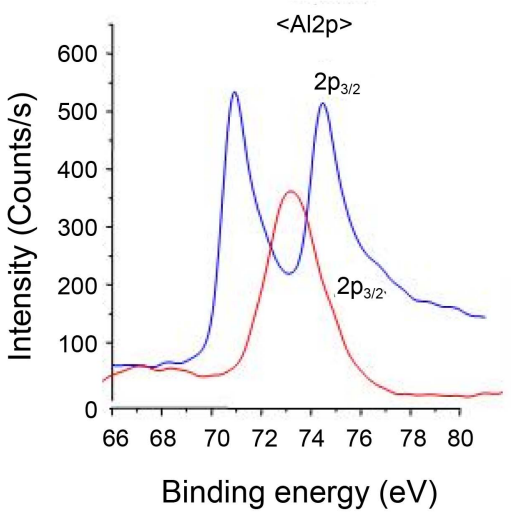

(b) $\mathrm{Ni} / \mathrm{Al}_{2} \mathrm{O}_{3}$

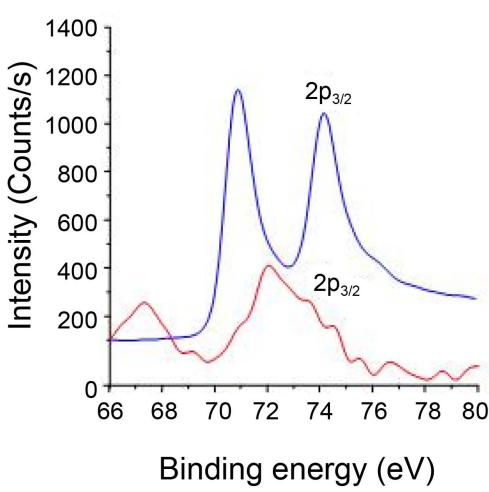

Before reaction $2 p_{3 / 2}$

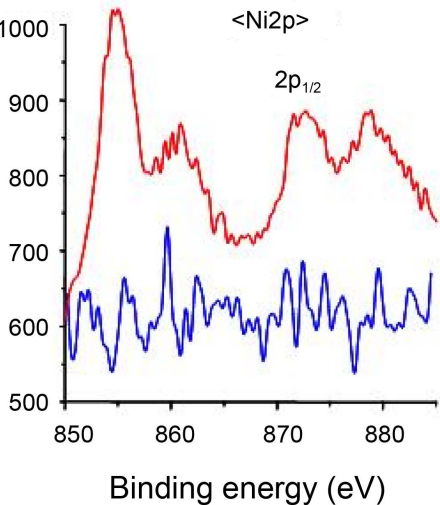

Binding energy $(\mathrm{eV})$

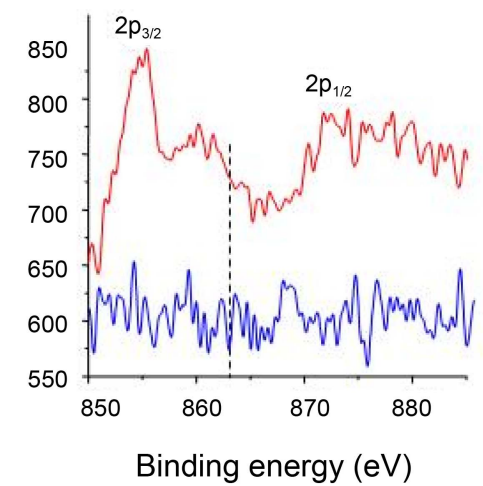

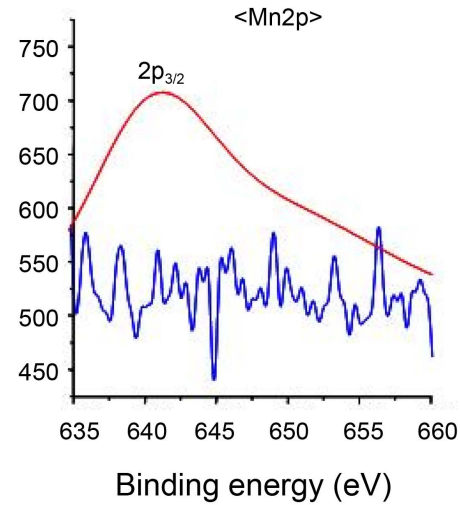

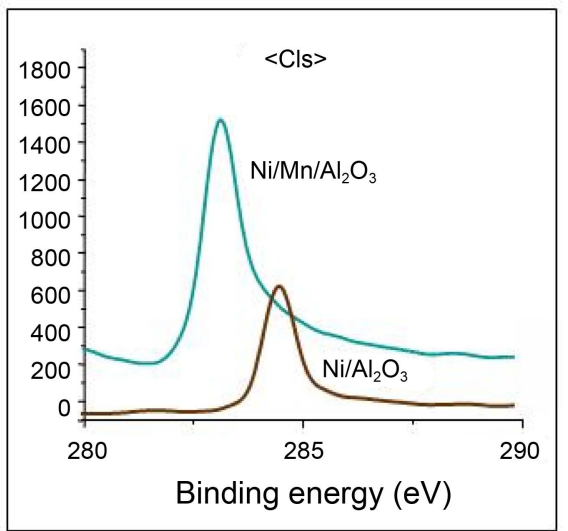

Figure 6. Comparison of the XPS curves for the $\mathrm{Al} 2 \mathrm{p}, \mathrm{Mn} 2 \mathrm{p}, \mathrm{Ni} 2 \mathrm{p}$, and $\mathrm{C} 1 \mathrm{~s}$ orbitals of the $\mathrm{Ni} / \gamma-\mathrm{Al}_{2} \mathrm{O}_{3}$ and Ni/Mn/ $\gamma-\mathrm{Al}_{2} \mathrm{O}_{3}$ materials before and after the reaction.

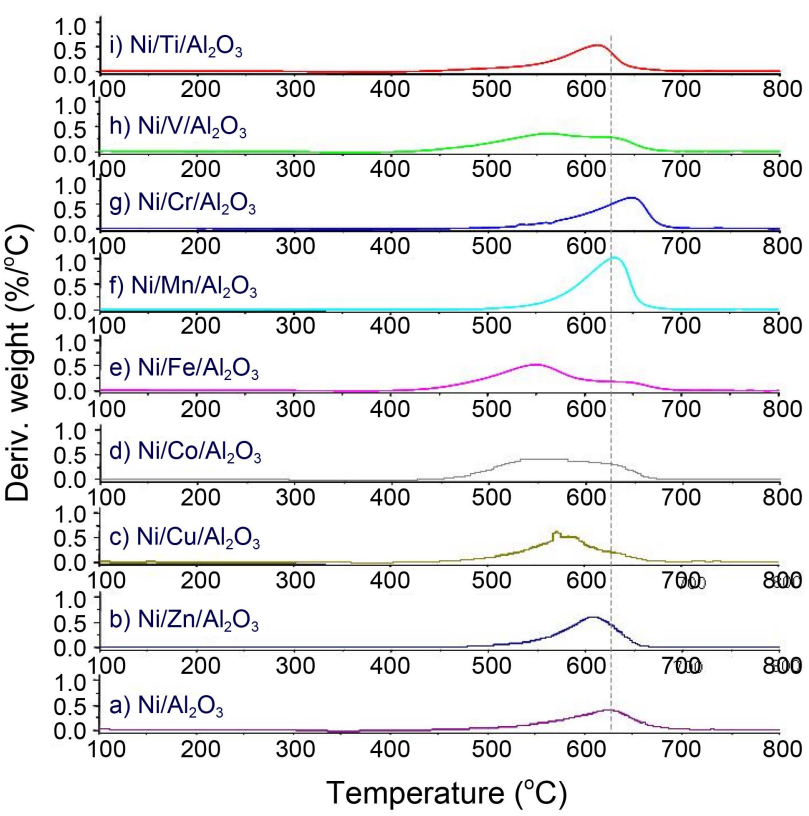

Figure 7. TPO profiles for the nine $\mathrm{Ni} / 3 \mathrm{~d}-\mathrm{M} / \gamma-\mathrm{Al}_{2} \mathrm{O}_{3}$ materials after the butane steam reforming.

related to the catalytic deactivation. Generally, the extent of the catalytic deactivation was reduced when smaller amounts of carbon were deposited. However, unfortunately, this behavior was not observed in this study. The deposited carbon amounts varied for the different $3 \mathrm{~d}$ metal species, and the combustion temperatures for carbon were also different. The XPS results revealed that different types of carbon accumulated on the surface of the material. No decomposition of the deposited carbon was evident on the $\mathrm{V}$, $\mathrm{Fe}, \mathrm{Co}$, and $\mathrm{Cu}$-loaded materials at around $550-650{ }^{\circ} \mathrm{C}$. With the addition of the $\mathrm{Mn}$ component to $\mathrm{Ni} / \gamma-\mathrm{Al}_{2} \mathrm{O}_{3}$, the amount of deposited carbon slightly increased compared to $\mathrm{Ni} /$ $\gamma-\mathrm{Al}_{2} \mathrm{O}_{3}$, without changing the combustion temperature. This was probably because the butane steam reforming strongly and rapidly occurred evenly over the surfaces of all of the metals on the $\mathrm{Ni} / \mathrm{Mn} / \gamma-\mathrm{Al}_{2} \mathrm{O}_{4}$ samples.

Optimum Conditions for Butane Reforming. Figure 8 shows the catalytic performances for the butane reforming reaction over the $\mathrm{Ni} / \mathrm{Mn} / \gamma-\mathrm{Al}_{2} \mathrm{O}_{3}$ materials with various Ni:Mn ratios of 0.1:0.3, 0.3:0.1, and 0.3:0.3 at a GHSV $=$ $5500 \mathrm{~h}^{-1}$ and a $n-\mathrm{C}_{4} \mathrm{H}_{10}: \mathrm{H}_{2} \mathrm{O}$ mole ratio $=1: 4$. Both the butane conversion and the $\mathrm{H}_{2}$ yield improved in almost all of the Mn-loaded samples compared to the catalyst without the Mn component because of the synergistic effect. When the $\mathrm{Ni}$ loading was larger than amount of $\mathrm{Mn}$, the reaction occurred at a higher temperature and the $\mathrm{H}_{2}$ production was minimized. Particularly, the butane conversion was about $100 \%$ at $450{ }^{\circ} \mathrm{C}$ for the catalyst with the atomic ratio of 

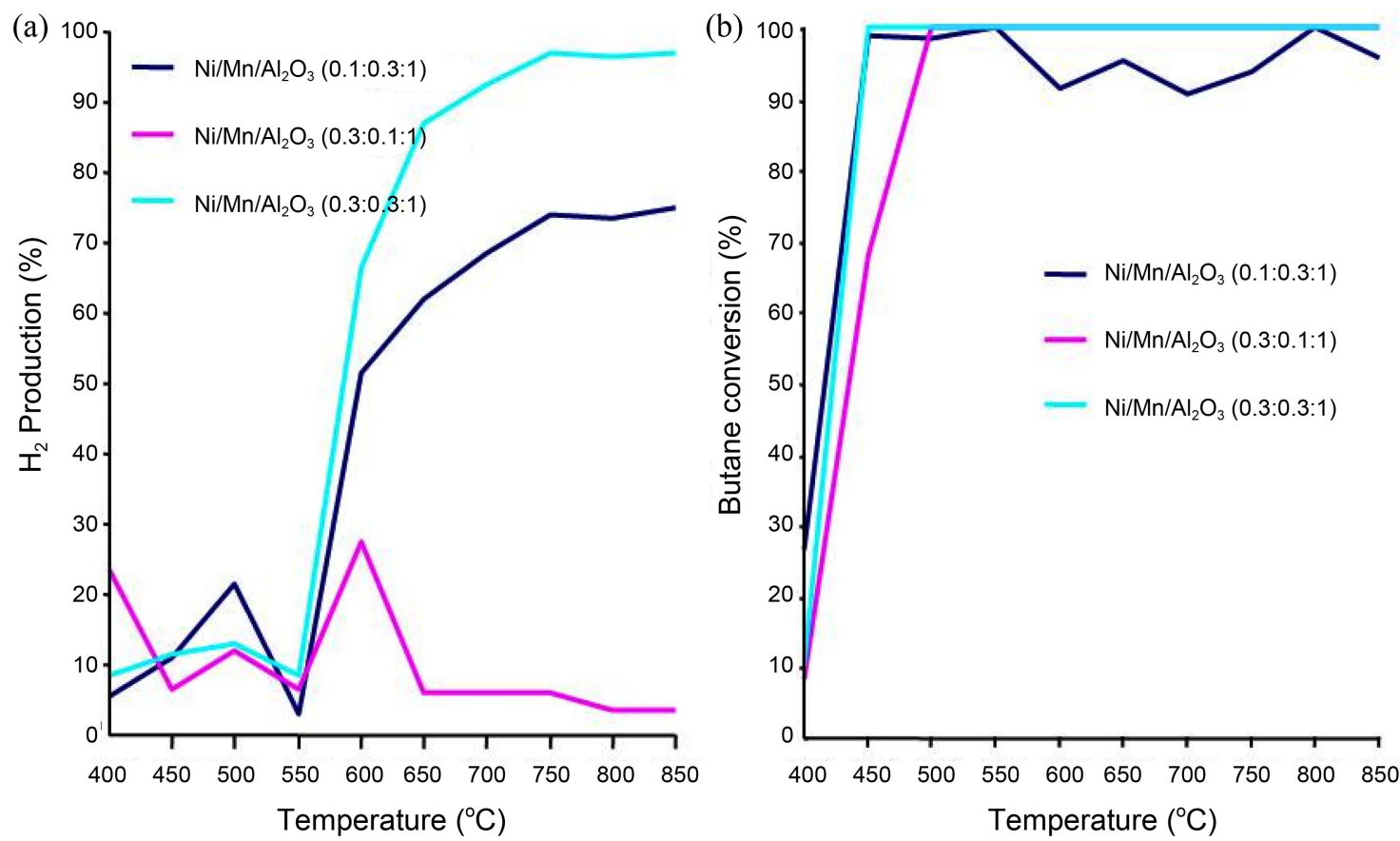

Figure 8. Butane conversion and $\mathrm{H}_{2}$ production over $\mathrm{Ni} / \mathrm{Mn} / \gamma-\mathrm{Al}_{2} \mathrm{O}_{3}$ according to the molar ratio of Ni/Mn: (a) $\mathrm{H}_{2}$ production and (b) butane conversion.

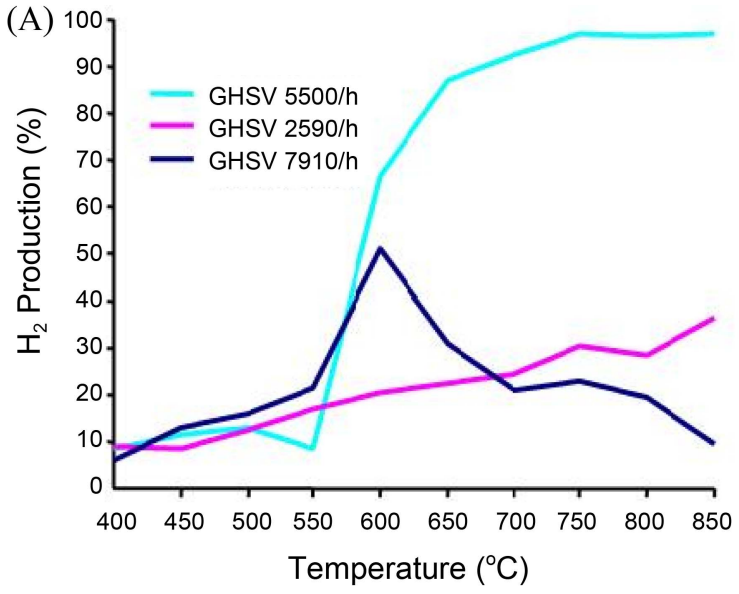

(a)

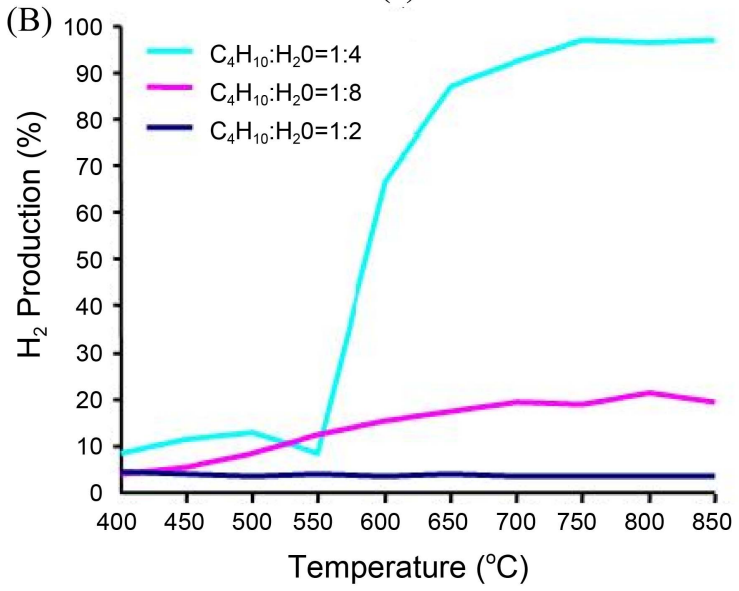

(a)

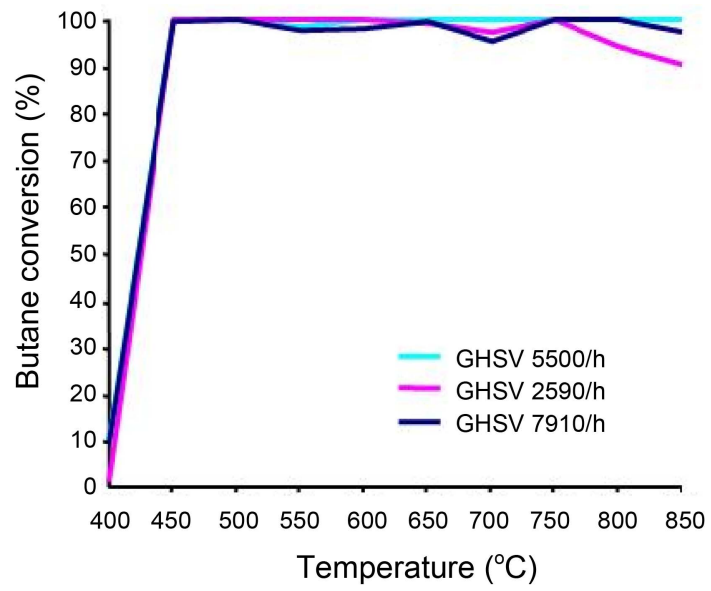

(b)

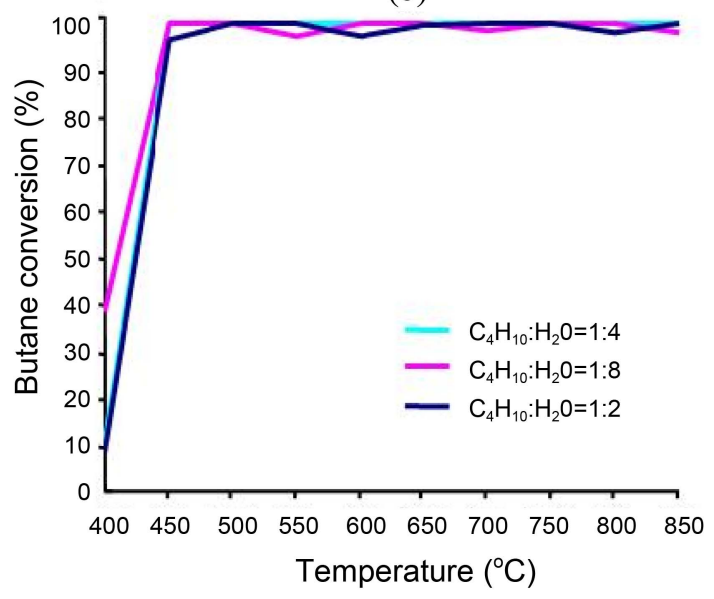

(b)

Figure 9. (a) $\mathrm{H}_{2}$ production and (b) butane conversion over $\mathrm{Ni} / \mathrm{Mn} / \mathrm{Al}_{2} \mathrm{O}_{3}$ with respect to (A) the $\mathrm{GHSV}$ and (B) the molar ratio of $\mathrm{C}_{4} \mathrm{H}_{10} / \mathrm{H}_{2}$. 


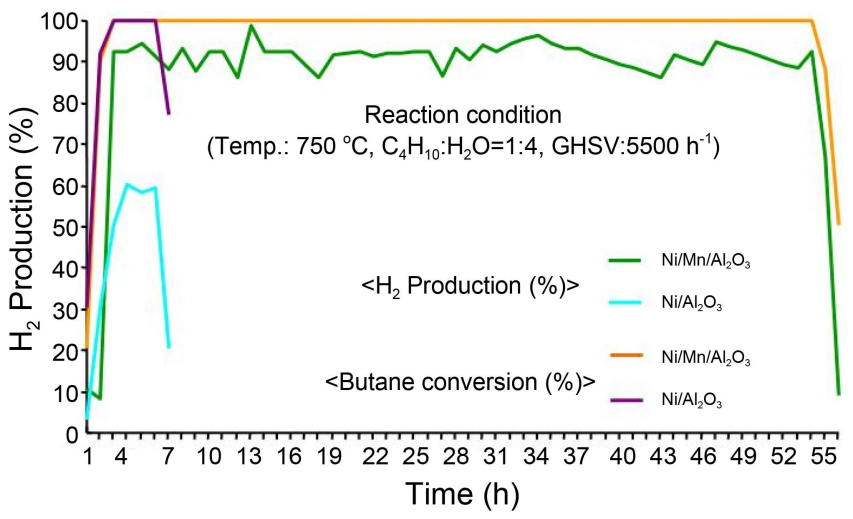

Figure 10. Catalytic deactivation tests over $\mathrm{Ni} / \gamma-\mathrm{Al}_{2} \mathrm{O}_{3}$ and $\mathrm{Ni} / \mathrm{Mn} /$ $\gamma-\mathrm{Al}_{2} \mathrm{O}_{3}$. Reaction conditions: $0.5 \mathrm{~g}$ sample, reaction temperature $=$ $750{ }^{\circ} \mathrm{C}$, GHSV $=5500 \mathrm{~h}^{-1}$, and $\mathrm{H}_{2} \mathrm{O} / n-\mathrm{C}_{4} \mathrm{H}_{10}=4.0$.

$\mathrm{Ni}: \mathrm{Mn}=0.3: 0.3$, and the butane was selectively converted to hydrogen with a high yield of $95 \%$ from 750 to $850{ }^{\circ} \mathrm{C}$. Otherwise, the catalytic performance was rather poor when too much Mn was added. The best performance was observed for the $\mathrm{Ni}(0.3) / \mathrm{Mn}(0.3) / \gamma-\mathrm{Al}_{2} \mathrm{O}_{3}(1.0)$ catalyst.

Figure $9 \mathrm{~A}$ and $\mathrm{B}$ show the catalytic performances for the butane steam reforming reaction over $\mathrm{Ni}(0.3) / \mathrm{Mn}(0.3)$ / $\gamma-\mathrm{Al}_{2} \mathrm{O}_{3}(1.0)$ with respect to changes in the GHSV and the butane $\left(n-\mathrm{C}_{4} \mathrm{H}_{10}\right) /$ steam $\left(\mathrm{H}_{2} \mathrm{O}\right)$ ratio, respectively. Figure $\mathrm{A}$ shows that the $\mathrm{H}_{2}$ production significantly improved at a reaction temperature $550{ }^{\circ} \mathrm{C}$ to $95 \%$ at $750{ }^{\circ} \mathrm{C}$ with a butane conversion of $100 \%$ at a GHSV of $5500 \mathrm{~h}^{-1}$. However, the catalytic performance decreased at lower or higher GHSVs. The optimum condition was $n-\mathrm{C}_{4} \mathrm{H}_{10}: \mathrm{H}_{2} \mathrm{O}=1: 4$ and $95 \%$ of the hydrogen was emitted at $750{ }^{\circ} \mathrm{C}$ with a butane conversion of $100 \%$, as shown in Figure B. However, the hydrogen production decreased above this ratio. Therefore, the optimal reaction conditions for the production of $\mathrm{H}_{2}$ over the $\mathrm{Ni}(0.3)$ / $\mathrm{Mn}(0.3) / \gamma-\mathrm{Al}_{2} \mathrm{O}_{3}(1.0)$ catalyst were GHSV $=5500 \mathrm{~h}^{-1}, n$ $\mathrm{C}_{4} \mathrm{H}_{10}: \mathrm{H}_{2} \mathrm{O}$ mole ratio $=1: 4$, and reaction temperature $=750$ ${ }^{\circ} \mathrm{C}$ according to the active response.

Finally, the catalytic deactivation was tested for the $\mathrm{Ni}$ / $\gamma-\mathrm{Al}_{2} \mathrm{O}_{3}$ and $\mathrm{Ni} / \mathrm{Mn} / \gamma-\mathrm{Al}_{2} \mathrm{O}_{3}$ catalysts, and the results are shown in Figure 10. The difference in the $\mathrm{H}_{2}$ production between these two catalysts was $0.3 \%$ depending on the presence or absence of $\mathrm{Mn}$. The catalytic lifetime was greatly improved in $\mathrm{Ni} / \mathrm{Mn} / \gamma-\mathrm{Al}_{2} \mathrm{O}_{3}$ compared to the material without $\mathrm{Mn}$. The catalytic deactivation remarkably progressed after only $7 \mathrm{~h}$ over $\mathrm{Ni} / \gamma-\mathrm{Al}_{2} \mathrm{O}_{3}$, and both the $\mathrm{H}_{2}$ production and the butane reforming rapidly decreased. The rapid deactivation over $\mathrm{Ni} / \gamma-\mathrm{Al}_{2} \mathrm{O}_{3}$ indicated that the initial catalyst deactivation resulted from a combination of the steaminduced nickel sintering and the carbon deposition. However, the apparent deactivation rate was far lower for the Mn-promoted catalyst, and its higher butane conversion of $100 \%$ and $\mathrm{H}_{2}$ yield of $85-98 \%$ continued for up to $55 \mathrm{~h}$. Thus, the improved stability that was achieved with the $\mathrm{Ni} / \mathrm{Mn}$ sample at the slower deactivation rate could not unequivocally be attributed to the carbon formation.

\section{Conclusion}

In this present work, the $3 \mathrm{~d}$ transition metals were added between $\mathrm{Ni}$ and $\mathrm{Al}$ in an attempt to decrease the catalytic deactivation that was induced by the strong sintering between $\mathrm{Ni}$ and $\mathrm{Al}$ during butane steam reforming, while simultaneously improving the catalytic activity. The study results confirmed that the catalytic performances differed with respect to the $3 \mathrm{~d}$ metal species. Particularly, the addition of the Mn component maybe helped to retain the stability of the Ni-Al crystallites and prevent their conglomeration during the butane steam reforming. The catalytic performance decreased in the following order: $\mathrm{Ni} / \mathrm{Mn}>$ $\mathrm{Co}>\mathrm{V}>\mathrm{Ti}>\mathrm{Zn}>$ non-metal $>\mathrm{Fe}>\mathrm{Cr} / \gamma-\mathrm{Al}_{2} \mathrm{O}_{3}$. The $\mathrm{H}_{2}$ production and butane conversion reached $95 \%$ and $100 \%$, respectively, over $\mathrm{Ni}(0.3) / \mathrm{Mn}(0.3) / \gamma-\mathrm{Al}_{2} \mathrm{O}_{3}(1.0)$ for up to 55 $\mathrm{h}$ without any catalytic deactivation. The optimal operation conditions were identified as a reaction temperature of 750 ${ }^{\circ} \mathrm{C}$, a gas hourly space velocity (GHSV) of $5500 \mathrm{~h}^{-1}$, and a feed ratio of $n-\mathrm{C}_{4} \mathrm{H}_{10}: \mathrm{H}_{2} \mathrm{O}$ of 1:4.

Acknowledgments. This work was supported by the New \& Renewable Energy of the Korea Institute of Energy Technology Evaluation and Planning (KETEP) grant funded by the Korea government Ministry of Knowledge Economy (No. 2010T100100622).

\section{References}

1. Avcl, A. K.; Önsan, Z. I.; Trimm, D. L. Appl. Catal. A 2001, 216, 243.

2. Avcl, A. K.; Trimm, D. L.; Aksoylu, A. E.; Önsan, Z. I. Appl. Catal. A 2004, 258, 235.

3. Chin, Y. H.; King, D. L.; Roh, H. S.; Wang, Y.; Heald, S. M. J. Catal. 2006, 244, 153.

4. Xu, J.; Chen, L.; Tana, K. F.; Borgna, A.; Saeys, M. J. Catal. 2009, 261, 158 .

5. Kroll, V. C. H.; Swaan, H. M.; Mirodatos, C. J. Catal. 1996, 161, 409.

6. Rostrup-Nielsen, J. R.; Anderson, J. R.; Boudart, M. Catalytic Steam Reforming, Catalysis Science and Technology; SpringerVerlag: Berlin, 1984, Vol. 5, chap. 1.

7. Swaan, H. M.; Kroll, V. C. H.; Martin, G. A.; Mirodatos, C. Catal. Today 1994, 21, 571.

8. Wei, J.; Iglesia, E. J. Catal. 2004, 224, 370.

9. Gökaliler, F.; Göçmen, B. A.; Aksoylu, A. E. Int. J. Hydrogen Energy 2008, 33, 4358.

10. Sato, K.; Nagaoka, K.; Nishiguchim, H.; Takita, Y. Int. J. Hydrogen Energy 2009, 34, 333.

11. Jeong, H.; Kang, M. Appl. Catal. B 2010, 95, 446.

12. Nie, X.; Meletis, E. I.; Jiang, J. C.; Leyland, A.; Yerokhin, A. L.; Matthews, A. Surf. Coat. Tech. 2002, 149, 245.

13. Hirano, H.; Tanaka, K. I. J. Catal. 1992, 133, 461.

14. Du, G.; Lim, S.; Yang, Y.; Wang, C.; Pfefferle, L.; Haller, G. L. J. Catal. 2007, 249, 370.

15. Ma, L.; Trimm, D. L.; Jiang, C. Appl. Catal. A 1996, 138, 275.

16. Sago, F.; Fukuda, S.; Sato, K.; Nagaoka, K.; Nishiguchi, H.; Takita, Y. Int. J. Hydrogen Energy 2009, 34, 8046.

17. Seo, J. G.; Youn, M. H.; Song, I. K. Int. J. Hydrogen Energy 2009, $34,1809$.

18. Mazzieri, V.; Coloma-Pascual, F.; Arcoya, A.; L'Argentière, P. C.; Fígoli, N. S. Appl. Surf. Sci. 2003, 210, 222. 